\title{
Rady przyjacielskie młodemu czcicielowi nauk i filozofii, pragnącemu znaleźć pewniejszą drogę do prawdziwego i wyższego oświecenia
}

Prezentowany poniżej tekst stanowi zapis fragmentu notatek Józefa Kalasantego Szaniawskiego do jego głównej rozprawy zatytułowanej Rady przyjacielskie młodemu czcicielowi nauk i filozofi, pragnącemu znaleźć pewniejsza drogę do prawdziwego i wyższego oświecenia (Warszawa 1805, Lwów 1823²). Trzy karty rękopisu tej rozprawy (odpowiadające kolejno stronom 57-59, 79-81 i 231-233 wydania lwowskiego) odnalezione zostały niedawno w Bibliotece im. Zielińskich w Płocku.

Rękopis zawiera trzy karty formatu 18 x $21 \mathrm{~cm}$ złożone na pół i zapisane jak zeszyt, jednostronnie z komentarzami i uwagami na lewym, szerokim marginesie. Karty przechowywane były wraz z rękopisem fragmentu innej rozprawy Szaniawskiego Użyteczność, wpływ i zalety pięknych kunsztów. Jedna z kart rękopisu Rad przyjacielskich... pełniła funkcję okładki całego zbioru. O ile mi wiadomo, jest to jedyny zachowany fragment rękopisu najbardziej znanej filozoficznej rozprawy Szaniawskiego.

W tekście w minimalnym stopniu uwspółcześniono pisownię. Kursywą zaznaczono fragmenty tekstu nieobecne $\mathrm{w}$ ogóle bądź zmienione w edycji drukowanej (na podstawie porównania $\mathrm{z}$ wydaniem lwowskim). Frazy dodane $\mathrm{w}$ manuskrypcie nad tekstem głównym zapisano tu mniejszą czcionką w indeksie górnym. Podkreślenia zastąpiono drukiem rozstrzelonym, ale 
zachowano oryginalne przekreślenia. Wszelkie uwagi dodane w niniejszym opracowaniu umieszczono w nawiasach kwadratowych.

Tomasz Kupś

Karta 1, strona 1 (s. 57-59)

Przysposobnicze nauki i wiadomości. - Języki. - Matematyka. - Logika. Antropologia $z$ psychologia połaczona. $\left[{ }^{1}\right]$

Wprzedsiewzietej reformie unystowej uprawy nie możesz zakladá́
sobie [...]

Ścieśniałbyś i upośledzał zamiar przedsięwziętego doskonalenia umysłowej uprawy, gdybyś skutki jej zakładał wyłącznie na nabyciu, tej lub owej, pojedynczej nauki. Owocem takowej reformy powinno być najdokładniejsze [, ile podobna,] rozpostarcie władz i zdolności twoich; abyś w przyszłych jakiegokolwiek rodzaju badaniach mógł, z zupełną wolnością, $z$ najskuteczniejszą siłą, i w kierunku najprzyzwoitszym, używać wszystkich od natury odebranych usposobień. Należy ci dążyć do wolnowładnego nad nimi panowania, i w rozjaśnionym przeświadczeniu o tym wszystkim co wewnętrnie posiadasz, szukać owej uszczęsliwiającej pełności życia umysłowego. Nie lekkich więc usiłowań wymaga przedsięwzięcie twoje: ależ czy wahać się będziesz nad wyborem, skoro chodzi rzecz o założenie podstawy prawdziewego udoskonalenia twojego? Do działalności i pracy całożytnej przeznaczonym jest człowiek, i

nil sine magno labore

Dii dedere vitae

[Na stronie lewej u góry:]

„te przysposobnicze będą razem i materią do uprawy i rozpościerania”

${ }^{1}$ Ostatnia fraza tytułu, wielokrotnie zmieniana w brudnopisie, pierwotnie brzmiała: „Logika. Psychologia. Antropologia” następnie „Logika i Psychologia”. Ostatecznie „Antropologia z psychologia połaczona”, w wersji drukowanej: „Nauki antropologijne”. 
[Na stronie lewej u dołu:]

„Dlatego nie jest to tak lekka rzecz

[tekst nieczytelny]"

Karta 1, strona 2

Trzeba, powtarzam, czasu znacznego i wytrwałej usilności na dokonanie tak ważnej refor my. To co dotą wskazałem do czynienia, ostrzega ciebie że rzecz nie jest łatwą; to co jeszeze następuje, doda jeszcze do liczby zatrudnień.

$\mathrm{Z}$ jednej strony, praca dostrzegań, które ci już zaleciłem, wymaga niejakiegoś przedmiotu, niejakiejś materii, na której by wykonywaną być mogła. Ocenianie np. stopnia tej lub owej zdolności, najlepiej czynionym być może w ciągu pracy nad jakąś nauką lub umiejętnością. -

Z drugiej strony, rozpościeranie, doskonalenie i uprawa zdolności i władz twoich, nie mogłoby być posuwanym, tylko $\mathrm{w}$ ciągu bada ${ }^{\text {nia poświęconego }}$ temu lub owemu rodzajowi wiadomości.

Wypada zatem, ${ }^{\text {z }}$ pomiędzy nauk i umiejętności, obrać sobie niektóre, za przedmiot ciaggej uprawy w czasie dopełniania reformy. Ale w wyborze takowym zwracać należy szczególniejszy wzgląd na te, które moga usposabiać ciebie do wszelkiego rodzaju badań, i dawać najskuteczniejsze rozpostarcie zdolnościom twoim. Są to nauki, jak je Diderot nazwał, instrumentalne; nauki usposobnicze, albo przygotownicze, których przyzwoite śledzenie ma wprowadzić ciebie na [...]

[Po lewej stronie, na wysokości akapitu zaczynającego się od słów „Wypada zatem...":]

trzeba więc obrać coś...

a to musi być przy sposobności...

Karta 2, strona 1 (s. 79-81)

2. M a te matyka

Każda nauka dwojako może być użyteczna: raz, że przyda się do tego, lub owego zamiaru w życiu potocznym, albo dostarcza prawd dla innej jakowej nauki; (użyteczność materialna) - powtóre, że praca na nabycie jej łożona podług dobrych prawide, dodaje do rozprzestrzenienia i ukrzepienia działalności 
umysłowej i czyni ucznia sposobniejszym do nabywania innych wiadomości, (użyteczność formalna). - Dwojaką tę użyteczność, zapewnia nam w stopniu najwyższym ${ }^{\text {nauka }}$ matematyki.

Odosabniając umyślnie wszelki wzgląd na różnice i przymioty ciał, rozmierza matematyk samą czystą przestrzeń i liczb stosunki oznacza. Że zaś wszystko, co mieściem w objẹcciu natury, musi zajmowác jakieś miejsce $\mathrm{w}$ przestrzeni, a bądź co do ilości, bądź co do miary, podpada pod_oznaczenia liczbowe - więc tym samym matematyka rozciąga swą użyteczność do wszystkich nauk, umiejętności, kunstów i przedsięwzięć, które mają za cel, bądź jaśniejsze po-

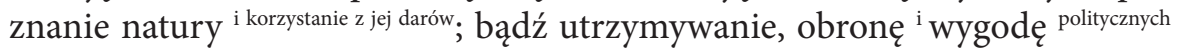
społeczeństw; bądź uprzyjemnienie życia człowieka. Od astrono mii, która, przez rozmaitość i wielkość swoich przedmiotów rozprzestrzeniając obraz wszechmocności przed obliczem rozumu; daje [Karta 2, strona 2] mu czuć siły jego i wzniesione nasze przeznaczenie, a razem upokarza przez widok niezmiernej dysproporcji, między rozumowymi objęciami $\left[{ }^{2}\right]$, a ogromem dzieł twórcy; - od astronomii, mówię, aż do ogrodniczego rozmiaru, lub do powszedniej pracy ${ }^{\text {parobka }}$ stró $\dot{z} a$, co za pomocą klinu palny pieniek rozszcze-

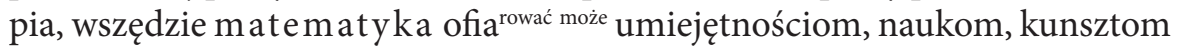

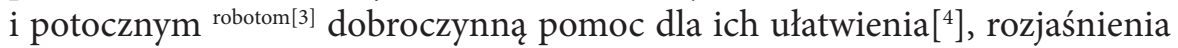
i udoskonalenia. Spójrz na tę coraz liczniej rozradzającą się familię nauk fizyko-matematycznych, z pomiędzy których jedne doszły już do wysokiego udoskonalenia, drugie wchodzą dopiero na tor rzeczywistych postępów, inne zaledwie ukazują zaród przyszłych nadziei; a poznasz, że bez matematyki, ani ci myśleć nie należy o przedsięwzięciu prac, przez które byś przyłożyé się cheiał do niedadaleko dojść możesz w pracach ${ }^{[5]}$, które bezpośredni mają związek z ulepszeniem fizycznego stanu[ $\left.{ }^{6}\right]$ społeczności. - Niepodaremnie ona w wyrazie prostego rozsądku, zowie się od dawna klu cze m do wszystkiego: - jej materialna użyteczność jest najobszerniejszą. Niepodobna jest nawet oznaczyć, jak daleko rozciągać się może wpływ jej w ciagu przyszłych naszych postępów: - niepodobna oznaczyć, jakiego plonu spodziewać się może$\mathrm{my} \mathrm{z}^{\text {rozszerzonych i }}$ udoskonalonych przystosowań jej do [...]

\footnotetext{
2 Brak: „człowieka”.

${ }^{3}$ Zamiast "pracom”.

${ }^{4}$ Zamiast „usiłowania”.

${ }^{5}$ W wersji drukowanej błąd: „parach”.

${ }^{6}$ W brulionie zachowane alternatywne określenia „dobra”, „stanu”.
} 
Karta 3, strona 1 (s. 231-233)

\section{Badania i życie pod przewodem mądrości[ $\left.{ }^{7}\right]$}

Dotąd przeprowadzałem cię po większej części przez naukę szkoły, wskazywałem ė obce źródła posiłków, przestając na budzeniu i otrzeźwianiu sa mo woln ej badaczego ducha działalności. Ale przyjdzie dla ciebie chwila, gdzie, po dokładnym zgłębieniu dziejów flozofii będziesz musiał zupetnie porzucić obce przewodnictwo, a powierzyć się twym własnym usiłowaniom. Wówczas przypomnisz sobie radę genialnego Herdera:

„Nabywaj szkolnych nauk Oddaj się naukom szkoły; ale [tekst nieezytelny] niby ów

Leukothei pasek, rzuć one za sobą pomiędzy morskie

bałwany wały, skoro dopłyniesz do brzegu."

$\mathrm{Na}$ tych słowach powinienem już ukończyć rady moje: czyliż bowiem mogę mogę $\mathrm{Ci} \mathrm{w}$ tej mierze przełożyć myśl jakową, na którą byś ty sam nie trafil, jeżeli roztrząśniesz dojrzale to wszystko, co dotąd mówiłem, i jeżeli zasilisz się obcymi zapa[... duchem badaczym przebiegniesz całe dzieje filozofii? - Ale $\left[{ }^{8}\right]$ mniemam, że powinienem wcześnie przygotować cię do rozwagi nad obłąkaniem wielu uczonych, którzy zdają się przeznaczać umysłową swoją uprawę jedynie dla szkoły, a nie dla życia[ [9]. Przełożę ci więc niektóre $\left[{ }^{10}\right]$ tylko myśli, jako wskazówki $\left[{ }^{11}\right]$ do owej przyszłej rozwagi, abyś teraz już mógł widzieć, na czym [Karta 3, strona 2] kończyć się ma umysłowa uprawa twoja $\left[{ }^{12}\right]$. Przełożę one $\left[{ }^{13}\right]\left[{ }^{14}\right]$ w skróconej osnowie, bacząc że wywód ich, teraz byłby za wczesny, a za lat $3\left[{ }^{15}\right]$ lub $4{ }^{\text {nie }}$ będzie tobie potrzebny. Wten-

${ }^{7}$ Pierwotny tytuł rozdziału nie zawiera dopisku umieszczonego w wersji drukowanej: „Najwyższe punkta, ku którym ściągnąć należy wszelkie umysłowe badania”.

${ }^{8}$ W wersji drukowanej dodany fragment: „przyrzekłem ci wytknąć niektóre skazówki na tej drodze, którą własnodzielnie odbywać masz do filozofii; a do tego".

${ }^{9}$ Przypis Szaniawskiego zapisany u dołu strony: „To życie biorę tu w znaczeniu najrozleglejszym; jako nierozdzielną jednotę, łączącą razem życie fizyczne, u mysłowe i moralne..”

${ }^{10}$ W wersji drukowanej: „dorywcze”.

${ }^{11}$ W wersji drukowanej: „czyli bardziej napomknienia”.

${ }^{12}$ W wersji drukowanej: „dokąd dążyć maią skutki umysfowej uprawy twoiej”.

${ }^{13}$ W wersji drukowanej: „te”.

${ }^{14}$ W wersji drukowanej dodano: „myśli”.

${ }^{15}$ Ewidentny błąd w druku: „5” zamiast „3”. 
czas bowiem (jeżeli tylko odbędziesz $\left[{ }^{16}\right]$ należycie ów twardy nowicjat pracy, który był dotąd przedmiotem pisma ${ }^{\text {niniejszego }}$ ) wtenczas, mówię, będziesz mógłodrzucić [tekst nieczytelny] odrzucí powinieneś na stronę wszystkie pedagogiczno-przewodnicze ksiązki, a z nimi i moją teraźniejszą robotę; tak jak odrzucają się mechaniczne narzędzia po osięgnionym skutku, do którego [tekst nieczytelny] być miały pomocnymi. - Nie dziwuj się, że używam tego wyrazu - me chaniczne. Co w umysle piszącego autora nie było mechanizmem, ${ }^{\text {to }}$ dla ciebie, jako myślącego czytelnika, powinno być tylko pobudką i mechanicznym niejako pochodem $\left[{ }^{17}\right]$ dla obudzenia ${ }^{\text {oraz }}$ upłodnienia ducha twojego; - inaczej, ty sam zostałbyś czytającą machiną. Powinny cię zapewne[18] oświecać

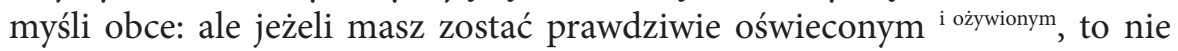
obcymi promieniami wchodzącymi do twego umysłu, ale własnym światłem, które $\mathrm{z}$ ich pomocą rozkrzesisz ${ }^{\text {sam w }}$ sobie $\left[{ }^{19}\right]$.

Zgłębiając (tak, jako tobie zaradziłem) dzieje filozofii, przebiegniesz całą prawie dziedzinę spekula cji i wszystkie niemal kierunki, pod którymi ona rozpościerać[ $\left[{ }^{20}\right]$ się może: już więc z jednej strony, - chcę mówić, ze strony głowy, - znajdziesz się zbliżonym ku celowi wyższej uprawy. Ale to nie jest dosyć. Nie na innej działalności umysłowej zależy pełność prawdziwego życia. Chociażby (co nie jest podobieństwem) znalazł już na drodze spekulacji zupełne dla rozumu zaspokojenie, tedy pozostałe ci jeszcze zjednać pokój serca, oczyścić i ukrzepić wolą. Dobrze w tej mierze [...]

\footnotetext{
${ }^{16}$ Słowo poprawione, pierwotnie „przebędziesz”.

${ }^{17}$ Tekst „tylko pobudką i mechanicznym niejako pochodem” dopisany na lewej stronie karty.

${ }^{18}$ W wersji drukowanej: „zaiste”.

${ }^{19}$ Całe zdanie dopisane na lewej stronie karty.

${ }^{20}$ W wersji drukowanej: „rozwijać”.
} 